\title{
Pengaruh Gelombang pada Profil Kemiringan Pantai Pasir Buatan (Uji Model Fisik dan Studi Kasus Penanggulangan Erosi serta Pendukung Konservasi Lingkungan Daerah Pantai)
}

\author{
Oki Setyandito ${ }^{1}$, Nizam $^{2}$, Nur Yuwono ${ }^{2}$, Radianta Triatmadja ${ }^{2}$ \\ ${ }^{I}$ Staf Pengajar Jurusan Teknik Sipil Fakultas Teknik Universitas Mataram NTB. \\ Kandidat Doktor, Program Studi Teknik Sipil,Fakultas Teknik, Universitas Gadjah Mada \\ e-mail: okisetyandito@yahoo.com \\ ${ }^{2}$ Profesor, Staf Pengajar pada Jurusan Teknik Sipil dan Lingkungan,Universitas Gadjah Mada
}

\begin{abstract}
Abstrak
Masalah utama di daerah pantai adalah erosi pantai yang terjadi akibat gempuran gelombang serta pembangunan konstruksi yang tidak akrab lingkungan. Salah satu usaha pengembangan daerah pantai yang sedang dan telah dilaksanakan adalah pembangunan pantai buatan (artificial beach nourishment). Pada tulisan ini disajikan hasil penelitian yang bertujuan untuk mengetahui pengaruh karakteristik gelombang (tinggi gelombang $H$, periode gelombang $T$ dan panjang gelombang $L$ ) terhadap Equilibrium Beach Profile (EBP) atau final slope $\left(n_{f}\right)$ (profil) yang terbentuk terutama pada area swash zones.

Uji model fisik 3-D dilakukan terhadap material penyusun pantai berupa pasir $\left(d_{50}=0,467-1,2 \mathrm{~mm}\right)$, dengan bangunan pelindung berupa gabungan groin I dan L. Model pantai pasir di tempatkan pada kolam gelombang, dengan initial slope $(n=6)$ dan dikenai gelombang reguler konstan hingga kondisi EBP tercapai. Untuk setiap model uji dilakukan variasi tinggi gelombang $(H)$ dan periode gelombang $(T)$.

Hasil penelitian menunjukkan EBP atau profil kemiringan stabil yang terbentuk dipengaruhi oleh karakteristik gelombang. Pada area terbuka, semakin besar $H_{0} / L_{0}$, profil yang terbentuk akan bergeser dari swell profile menjadi storm profile, yang ditunjukkan oleh terjadinya bar. Jika $H_{0} / L_{0}$ semakin besar, pantai akan semakin tegak (nilai $n_{f}$ semakin kecil), hal ini identik dengan hasil penelitian $2 \mathrm{D}$ dan studi kasus di pantai Sanur, Bali yang dilakukan Setyandito dkk. (2010) serta kajian teoritis dari penelitian sebelumnya. Landai akhir, $n_{f}$ yang terbentuk pada area terbuka pada hasil penelitian ini memiliki nilai 3 hingga 12 .
\end{abstract}

Kata kunci: profil kemiringan, pantai pasir buatan, uji model fisik, penanggulangan erosi, pendukung konservasi lingkungan daerah pantai

\section{Pendahuluan}

Beberapa pantai pasir di Indonesia yang merupakan kawasan wisata berkurang (garis pantainya mundur) akibat adanya proses erosi. Agar pantai tersebut masih dapat dipertahankan sebagai kawasan wisata maka perlu dilakukan revitalisasi kawasan tersebut dengan melakukan pemulihan kembali. Salah satu cara adalah dengan pantai pasir buatan atau artificial beach nourishment. Artificial beach nourishment bertujuan untuk menambah lebar pantai dan melindungi pantai dengan konsep menyediakan sejumlah pasir untuk dibawa oleh longshore current sehingga arus tersebut tidak mengikis pantai, serta menyediakan cadangan pasir yang sewaktu-waktu dibutuhkan, terutama pada saat badai dapat terangkut oleh cross-shore current. 

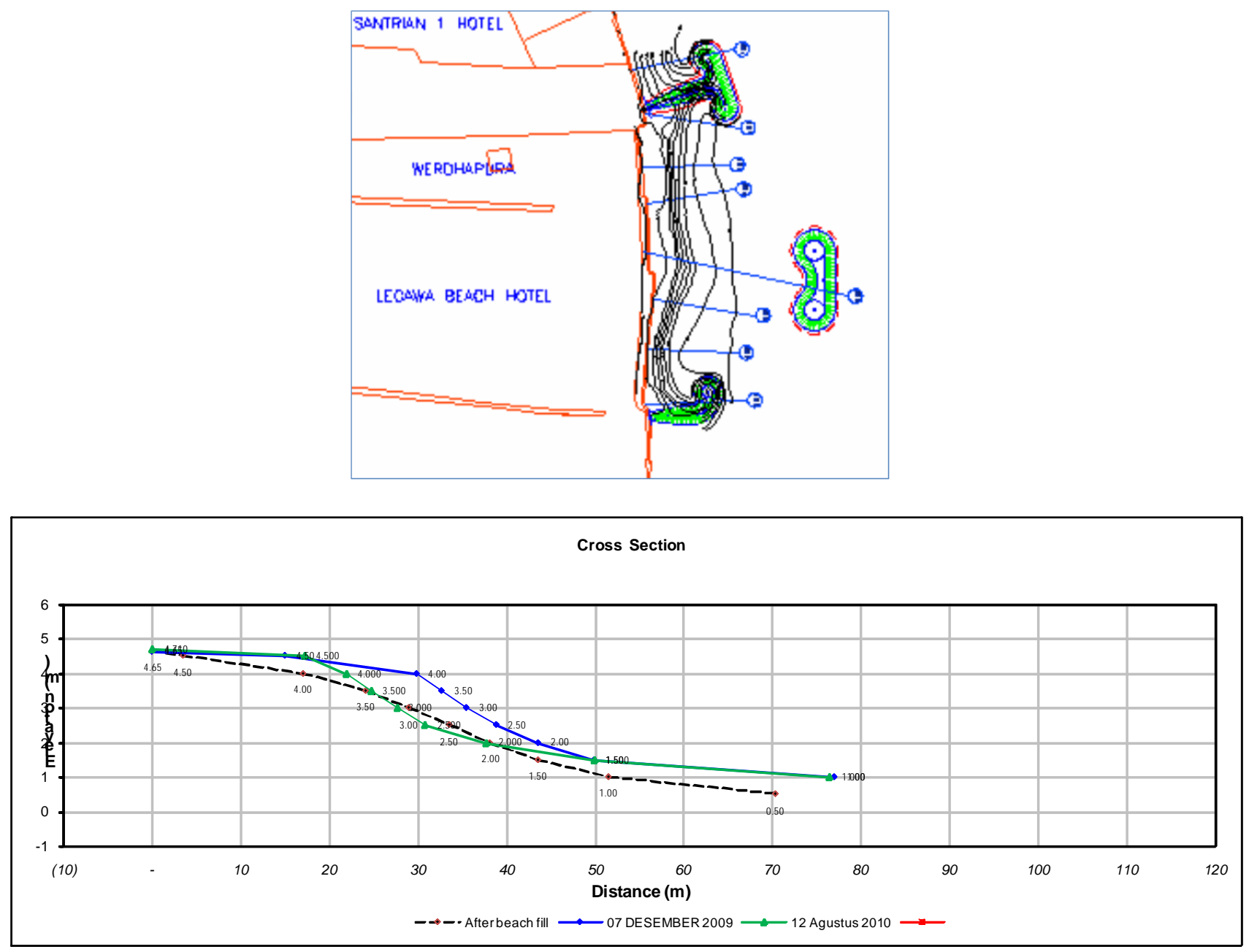

Gambar 1. Contoh perubahan profil dan kemiringan pada artificial beach nourishment di Pantai Sanur Bali. (Hasil studi kasus dan pengukuran yang dilakukan PSIT - UGM dan BWS Penida, 2009)

Interaksi antara struktur perlindungan pantai dan dinamika profil pantai serta garis pantai perlu dikaji dengan baik agar bisa dirumuskan kondisi pantai stabil pada kondisi perlindungan pantai yang berbeda-beda. Dengan demikian akan bisa dirumuskan pola penanganan kerusakan pantai berpasir dengan struktur yang tepat.

Masih banyak diperlukan suatu kajian yang lebih mendalam mengenai perlindungan atau pengamanan pada pantai pasir buatan sehingga diperoleh pantai pasir yang stabil dengan karakteristik dan geometri struktur pelindung yang berbeda-beda, terutama yang disesuaikan dengan keadaan di Indonesia. Pendekatan perlindungan dengan pantai pasir buatan ini merupakan pilihan yang menarik karena dipandang lebih natural sebagai cara mitigasi bencana pesisir. Pada tulisan ini disajikan hasil penelitian uji model fisik pengaruh gelombang terhadap profil pantai pasir buatan stabil dengan struktur pelindungnya berupa gabungan groin I dan L. Pada Gambar 1 disajikan salah satu contoh perubahan layout garis pantai dan profil kemiringan di pantai Sanur, Bali. 


\section{Studi Pustaka dan Landasan Teori}

\section{Penerapan Pantai Pasir Buatan dan Profil Pantai Pasir Buatan}

Penerapan pantai pasir buatan sebagai pelindung pantai di Belanda telah dimulai sejak tahun 1970. Dean dan Dalrymple (2002) menyebutkan bahwa pada tahun 1976 hingga 1981 di Amerika Serikat dilaksanakan Miami Beach Nourishment Project di pantai pasir Miami sepanjang $16 \mathrm{~km}$. yang menambah lebar pantai 100 meter ke arah laut dan menggunakan sekitar 10 juta $\mathrm{m}^{3}$ pasir dari lepas pantai dengan biaya mencapai USD 64 juta. Proyek ini mendapat penghargaan karena efektifitasnya dan menjadi tujuan wisata utama di Amerika Serikat.

Erchinger (1984), dalam Van Rijn (1998), merumuskan bahwa tujuan utama dari pembangunan pantai pasir buatan adalah pembuatan dan atau restorasi pantai rekreasi, reklamasi pantai, pemeliharaan garis pantai, perkuatan dunes, perlindungan bangunan pantai dan pengurangan energi gelombang datang ke pantai.

Dalam perencanaan kelandaian pantai pasir buatan perlu diperhatikan kelandaian alami pantai dilokasi rencana pembangunan. Untuk memberikan pemahaman yang sama mengenai kelandaian, digunakan batasan sesuai dengan yang dilakukan oleh Yuwono (2004) sebagaimana yang diuraikan dalam Gambar 2. Kelandaian pantai pasir dapat diperkirakan menggunakan Tabel 1.

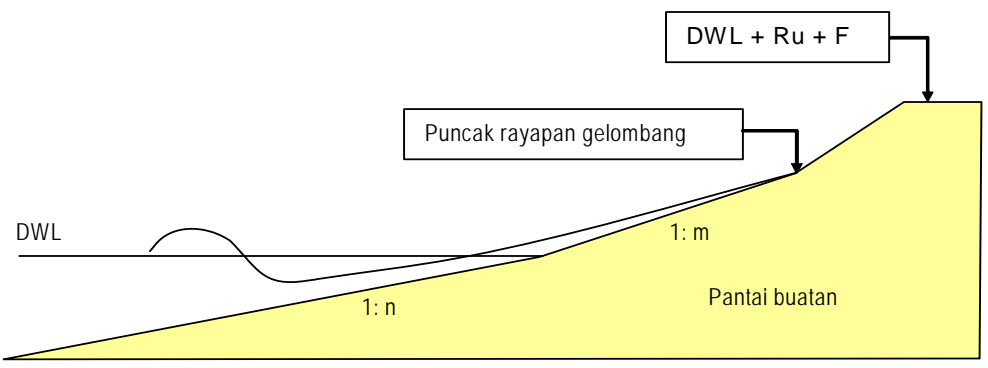

Gambar 2. Pembagian kelandaian pantai pasir (Yuwono, 2004)

Tabel 1. Hubungan diameter pasir dengan kelandaian pantai

\begin{tabular}{|c|c|c|c|c|}
\hline Diametar pasir & Pantai & dung & Pantai & uka \\
\hline $\mathrm{mm}$ & $\mathrm{n}$ & $\mathrm{m}$ & $\mathrm{n}$ & $\mathrm{m}$ \\
\hline 0,2 & $25-40$ & \multirow{4}{*}{$6-10$} & $40-100$ & \multirow{4}{*}{$10-15$} \\
\hline 0,3 & $12-20$ & & $20-40$ & \\
\hline 0,4 & $7-12$ & & $12-20$ & \\
\hline 0,5 & $6-10$ & & $10-15$ & \\
\hline
\end{tabular}

Sumber: Yuwono (2004)

Setyandito dkk. (2009) meneliti perubahan profil kelandaian pada pantai pasir, dengan kisaran diameter butiran 0,23 mm. sampai $1.4 \mathrm{~mm}$. Pembagian profil kelandaian akibat gelombang menjadi 3 zona, dimana pada setiap zona tersebut masing-masing memiliki mekanisme transport sedimen yang berbeda (lihat Gambar 3). 
Swart (1974) juga telah meneliti perubahan profil kelandaian pada pantai pasir, dengan kisaran diameter butiran $0,11 \mathrm{~mm}$. sampai $0.227 \mathrm{~mm}$. Dalam penelitiannya, Swart membagi pembentukan profil kelandaian akibat gelombang menjadi 3 zona, dimana pada setiap zona tersebut masingmasing memiliki mekanisme transport sedimen yang berbeda. Pembagian zona profil kelandaian berdasarkan Swart (1974) dan Bakker (1968) adalah, zona 1 (backshore) berada diatas run up gelombang, zona 2 (profil-D), dimana terjadi transpor sedimen yang disebabkan oleh gelombang, dan zona 3 adalah area transisi yang terbentuk karena gerakan dasar. Hasil penelitian Swart menunjukkan pada zona 1, semakin besar diameter partikel, semakin cepat kestabilan slope terjadi. Pada zone 3, semakin besar diameter partikel, kestabilan slope yang terjadi akan semakin lama.

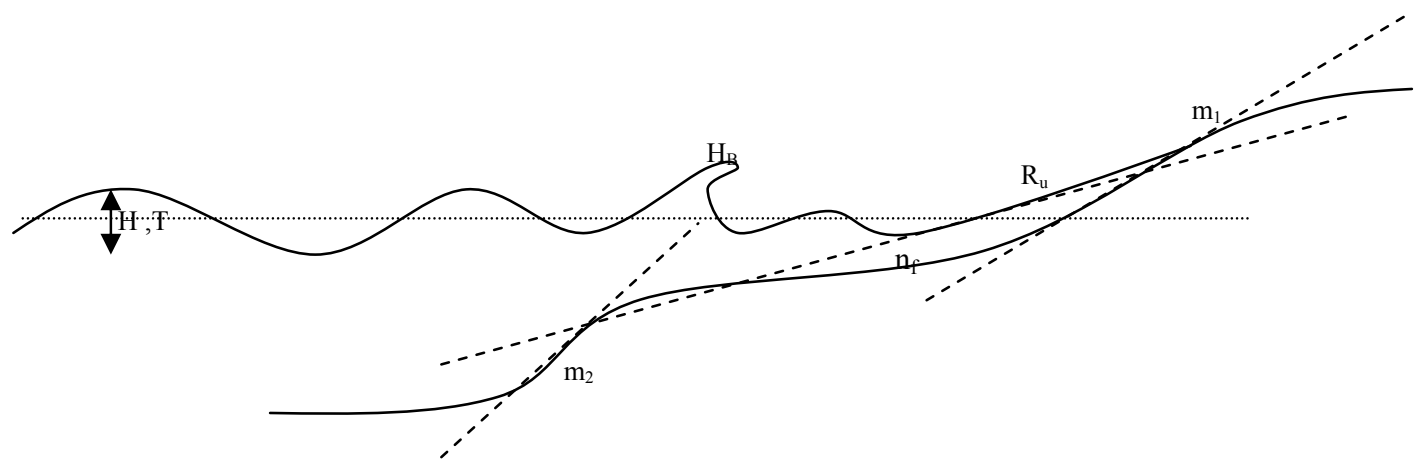

Gambar 3. Pembagian zona profil kelandaian pada pantai pasir buatan berdasarkan Setyandito (2009)

\section{Teori Gelombang Linear}

Menggunakan prinsip gelombang amplitude kecil, Airy menurunkan persamaan Laplace untuk aliran irrotasional dan melakukan linearisasi terhadap persamaan Bernoulli dan menghasilkan Teori Gelombang Airy dikenal juga sebagai Teori Gelombang Linear. Beberapa hasil penyelesaian terhadap persamaan Laplace adalah sebagai berikut:

$$
\begin{array}{ll}
\text { Elevasi muka air laut } & \eta=\frac{H}{2} \cos (k x-\sigma) \\
\text { Panjang gelombang } & L=\frac{g}{2 \pi} T^{2} \tanh \frac{2 \pi}{L} h
\end{array}
$$

\section{Gelombang Berdiri dan Gelombang Berdiri Parsial}

Gelombang berdiri sempurna adalah gabungan dari gelombang datang dan refleksi dengan tinggi, periode dan panjang gelombang yang sama:

$$
\eta_{c}=\eta_{i}+\eta_{r}=\frac{H_{i}}{2} \cos (k x-\sigma)+\frac{H_{r}}{2} \cos (k x+\sigma t)
$$


karena $H_{i}=H_{r}$ maka:

$$
\eta_{c}=H_{i} \cos (k x) \cos (\sigma t)
$$

saat $k x=n \pi$ dimana $(n=0,1,2, \ldots)$, fluktuasi air maksimum akan tercapai pada antinodes, sedanglan saat $k x=(n+1 / 2) \pi$ dimana $(n=0,1,2, \ldots)$, fluktuasi air akan minimum dan terbentuk anti nodes sebagaimana ditunjukkan pada Gambar 1. .a.

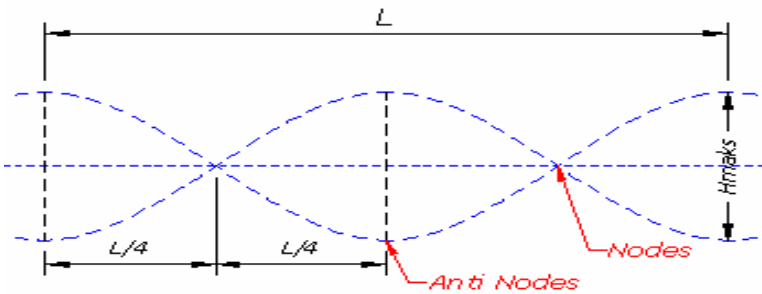

a. gelombang berdiri sempurna

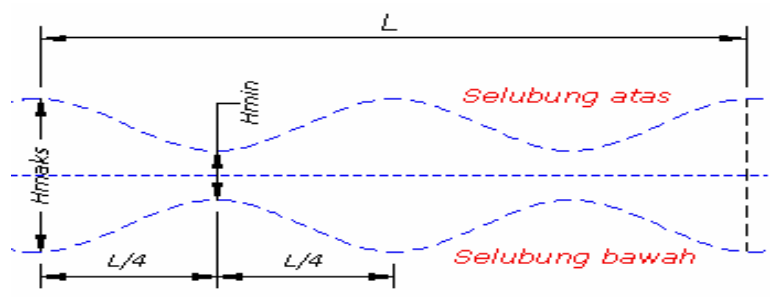

b. gelombang berdiri parsial

Gambar 1. Profil gelombang berdiri

Pada gelombang berdiri parsial, tidak seluruh energi gelombang datang dipantulkan sehingga $H_{i}>$ $H_{r}$, namun demikian periode dan panjang gelombang refleksi sama dengan periode dan panjang gelombang. Hal ini mengakibatkan tidak terbentuk nodes secara sempurna sebagaimana ditunjukkan pada Gambar 1. .b.

Sistem gelombang pada Persamaan (4) menjadi:

$$
\eta_{c}=\left(\frac{H_{i}}{2}+\frac{H_{r}}{2}\right) \cos (k x) \cos (\sigma t)+\left(\frac{H_{i}}{2}-\frac{H_{r}}{2}\right) \cos (k x) \cos (\sigma t)
$$

Jika nodes dan antinodes dianggap sebagai $H_{t}$ maksimal dan $H_{t}$ minimal, maka:

$$
\eta_{c \text { maks }}=\frac{H_{i}+H_{r}}{2} \text { dan } \eta_{c \min }=\frac{H_{i}-H_{r}}{2}
$$

dengan melakukan eliminasi persamaan di atas, diperoleh:

$$
H_{i}=\frac{H_{\text {maks }}+H_{\min }}{2} \text { dan } H_{r}=\frac{H_{\text {maks }}-H_{\min }}{2}
$$

\section{Gelombang dan Run up Gelombang}

Berdasarkan kajian semi teoritis dan eksperimen $R u$ yang dilakukan pada pantai pasir dengan kemiringan $\alpha$, Hunt (1959), merumuskan bahwa $R u=\sqrt{H L_{0}} \tan ^{2} \propto$, dengan $L_{0}=\frac{g T^{2}}{2 \pi}$, sehingga,

$$
R u=0.4 T \sqrt{g H} \tan -1 \times
$$




\section{Transmisi Gelombang di Belakang Pemecah Gelombang}

Unjuk kerja struktur hidraulik dalam meredam gelombang dipengaruhi oleh hal-hal sebagai berikut CERC (1984),:

a. karakteristik gelombang meliputi kedalaman air, periode, tinggi dan panjang gelombang,

b. tipe bangunan meliputi kekasaran dan permeabilitas permukaan,

c. geometri bangunan meliputi kemiringan, elevasi puncak relative terhadap SWL dan lebar puncak.

Dalam Horikawa (1978) disebutkan bahwa besar refleksi oleh suatu struktur hidraulik dapat dinyatakan menggunakan koefisien refleksi $\left(K_{r}\right)$ sebagai perbandingan antara tinggi gelombang refleksi $\left(H_{r}\right)$ terhadap tinggi gelombang datang $\left(\mathrm{H}_{\mathrm{i}}\right)$. Nilainya berkisar antara $0 \leq K_{r} \leq 1$. Besar transmisi dinyatakan dengan koefisien transmisi $\left(\mathrm{K}_{\mathrm{t}}\right)$, yaitu perbandingan antara tinggi gelombang transmisi $\left(\mathrm{H}_{\mathrm{t}}\right)$ terhadap tinggi gelombang datang $\left(H_{i}\right)$.Nilai koefisien transmisi berkisar antara $0<K_{t}<1$.

Apabila perbandingan antara tinggi gelombang refleksi dengan tinggi gelombang datang disebut dengan koefisien refleksi $(K r)$, sertaperbandingan antara tinggi gelombang transmisi dengan tinggi gelombang datang disebut koefisien transmisi $(\mathrm{Kt})$, dan koefisien kehilangan energi $(\mathrm{Ka})$, maka persamaan

$$
\mathrm{K}_{\mathrm{r}}^{2}+\mathrm{K}_{\mathrm{t}}^{2}+\mathrm{K}_{\mathrm{a}}=1
$$

dengan:

$$
\begin{aligned}
& K_{\tau}=\frac{H_{\tau}}{H_{i}}=\text { koefisien transmisi gelombang } \\
& K_{r}=\frac{H_{r}}{H_{i}}=\text { koefisien refleksi gelombang } \\
& K_{a}=\text { koefisien kehilangan energi }
\end{aligned}
$$

\section{Metodologi Penelitian}

Sesuai dengan tujuan yang telah ditetapkan, tulisan ini disusun berdasarkan kajian analisa hasil eksperimen di laboratorium (3-D) yang dibandingkan dengan hasil eksperimen $2 \mathrm{D}$ dan studi kasus di pantai Sanur Bali. Uji model fisik 3 D dengan model pantai pasir buatan disajikan pada Gambar 5 dan Gambar 6. 


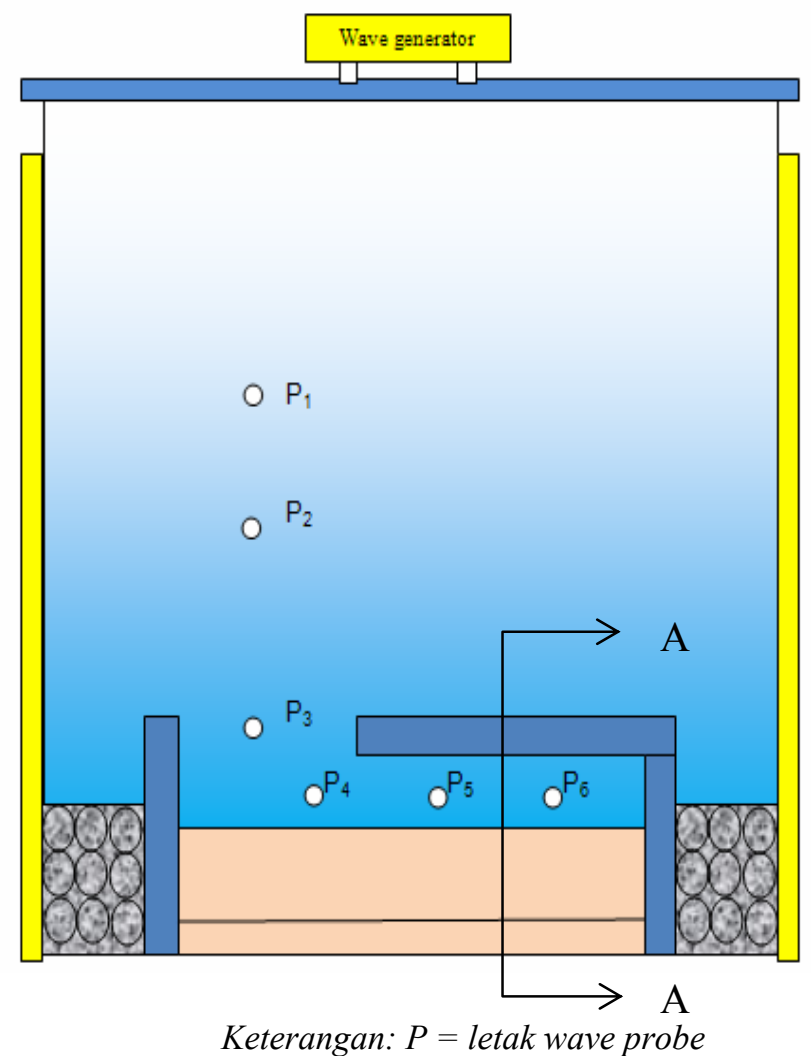

Gambar 5. Kolam gelombang penelitian $3 \mathrm{D}$, beserta model pantai pasir buatan dengan struktur pelindung gabungan Groin I dan L.

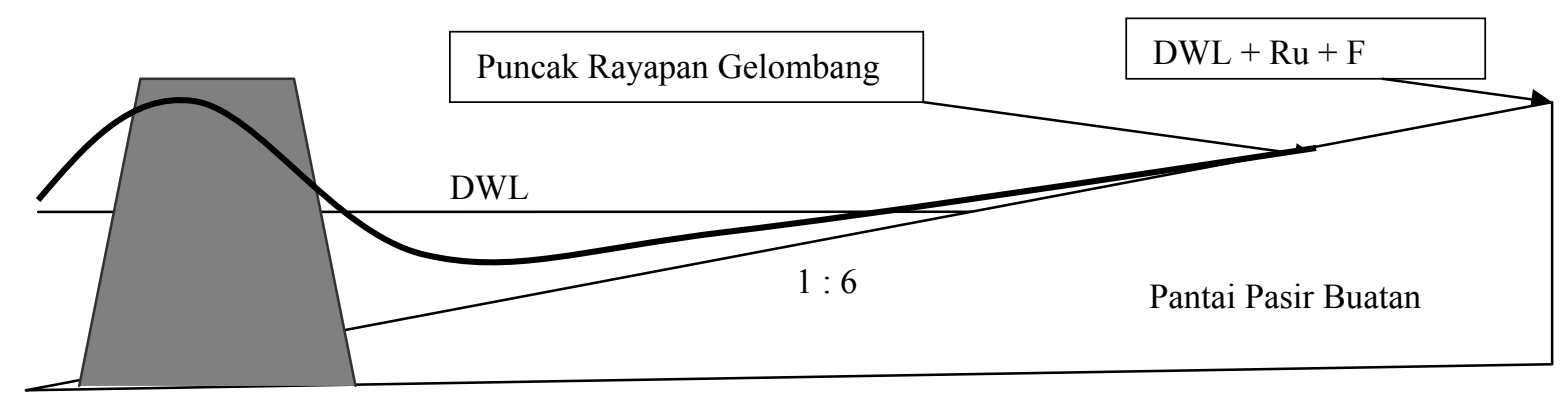

Keterangan: $D W L=$ Design Water Level; $R u=$ Run up; $F=$ Freeboard

Gambar 6. Profil kemiringan awal model pantai pasir. (Potongan A-A)

\section{Hasil dan Pembahasan}

\section{Data Tinggi dan Panjang Gelombang}

Data hasil pengukuran disajikan dalam grafik hubungan antara parameter tinggi gelombang terhadap kedalaman $(H / d)$ serta kedalaman terhadap panjang gelombang $(d / L)$ (Triatmodjo, 1999). Hasil analisa kondisi gelombang hasil penelitian 3-D disajikan dalam Gambar 7. 


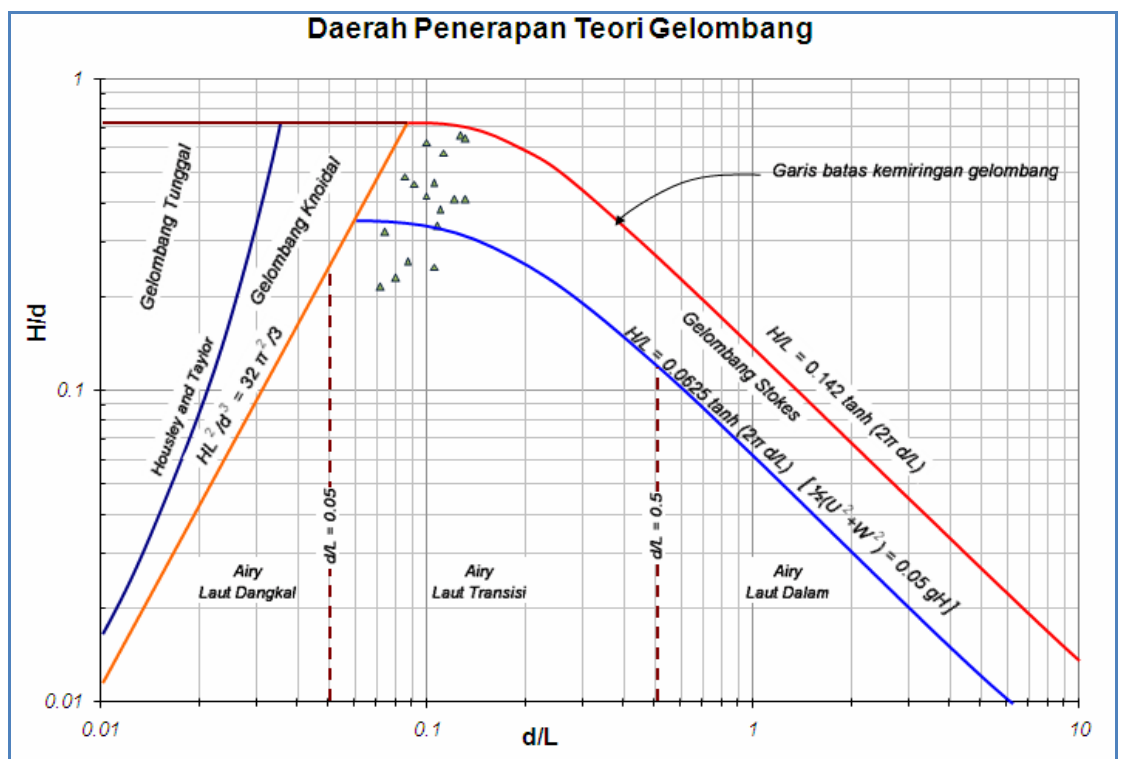

Gambar 7. Grafik hubungan d/L dengan $\mathrm{H} / \mathrm{d}$ hasil analisa gelombang hasil penelitian 3-D

Berdasarkan hasil perhitungan tinggi, periode, kedalaman air dan panjang gelombang dapat ditentukan tipe gelombang yang terbentuk, bahwa berdasarkan kedalaman relatif pada penelitian ini gelombang yang terjadi merupakan gelombang di laut transisi. Dimana nilai kedalaman relatif $(d / L)$ yang digunakan pada semua model berada pada $1 / 20<d / L<1 / 2$. Sebaran data penelitian yang tercantum dalam Gambar 7 memperlihatkan bahwa data berada pada daerah penerapan teori gelombang Airy laut transisi dan sebagian terletak pada penerapan teori gelombang Stokes. Sehingga untuk perhitungan dan analisis selanjutnya dilakukan berdasarkan teori gelombang Airy untuk laut transisi.

\section{Profil Kemiringan Stabil}

Hasil analisa profil stabil hasil uji model 3D disajikan pada Gambar 8. Formasi salient dan mulai terbentuknya tombolo terlihat jelas setelah dibandingkan dengan kondisi awal. Gambar 8 memperlihatkan contoh bentuk formasi pembentukan akhir berpindahnya material timbunan pada model C, dimana penampang melintang 6 (P6) merupakan penampang melintang ada zona terbuka, sedangkan penampang melintang 1 (P1) merupakan penampang melintang pada zona terlindung. Dari hasil analisa di peroleh bahwa penampang melintang 6 (P6) mempunyai kemiringan akhir (nf) berkisar 3-10. 


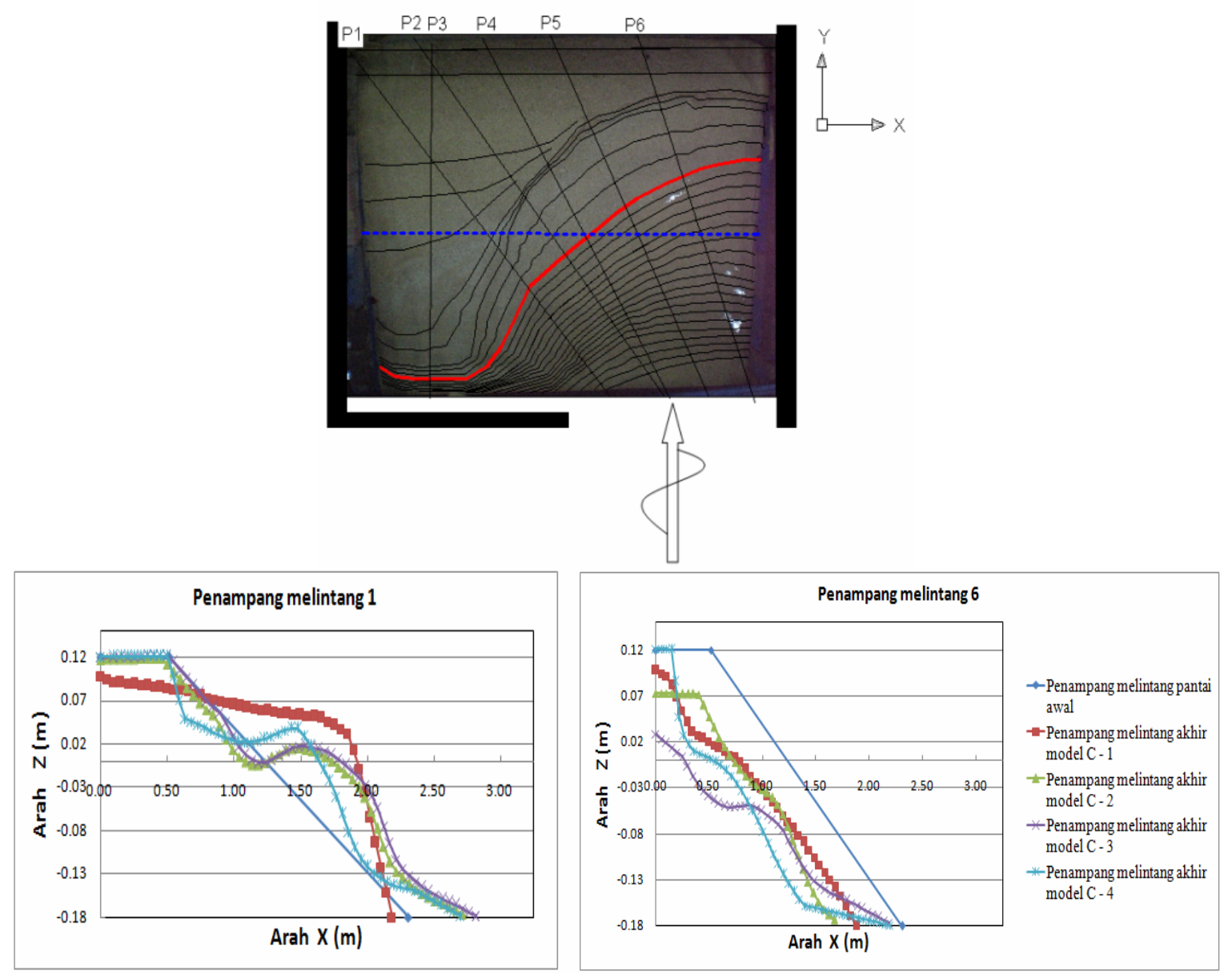

Gambar 8. Hasil analisa profil stabil, hasil uji model 3-D.

Grafik hasil kajian teoritis yang dilakukan oleh Hunt (1959) dan data hasil penelitian 2 D Setyandito dkk. (2009) disajikan pada Gambar 9. Pada grafik tersebut menunjukkan hubungan antar parameter kelandaian gelombang $\frac{H}{g T^{2}}$ dengan profil kemiringan $\left(\operatorname{sot} \boldsymbol{\alpha}=n_{f}\right)$. Hasil penelitian (Gambar 9.) menunjukkan bahwa semakin besar kelandaian gelombang, pantai akan semakin tegak.

Pada Gambar 10, juga disajikan hubungan antar parameter $H_{0} / L_{0}$ dan slope ( $\tan \propto$ ). Sebaran data hasil penelitian uji model fisik $3 \mathrm{D}$ serta studi kasus di lapangan, dengan dibandingkan oleh teori Miche (1961) disajikan pada Gambar 10. Tren grafik Miche (1961) menunjukkan bahwa kemiringan stabil yang terjadi adalah $0.1 \leq \tan \alpha \leq 1$ dengan $0.001<H_{0} / L_{0}<0.1$.

Hasil analisa uji model fisik 3 D untuk daerah terbuka, menunjukkan bahwa kemiringan stabil yang terjadi adalah berkisar $0.22 \leq \tan \alpha \leq 0.35$ dimana terjadi bar dengan kondisi $0.04<H_{0} / L_{0}<0.105$. Dari hasil analisa pengukuran di lapangan didapat bahwa kemiringan stabil yang terjadi adalah 0.1 $\leq \tan \alpha \leq 0.2$ dengan $0.04<H_{0} / L_{0}<0.11$. 


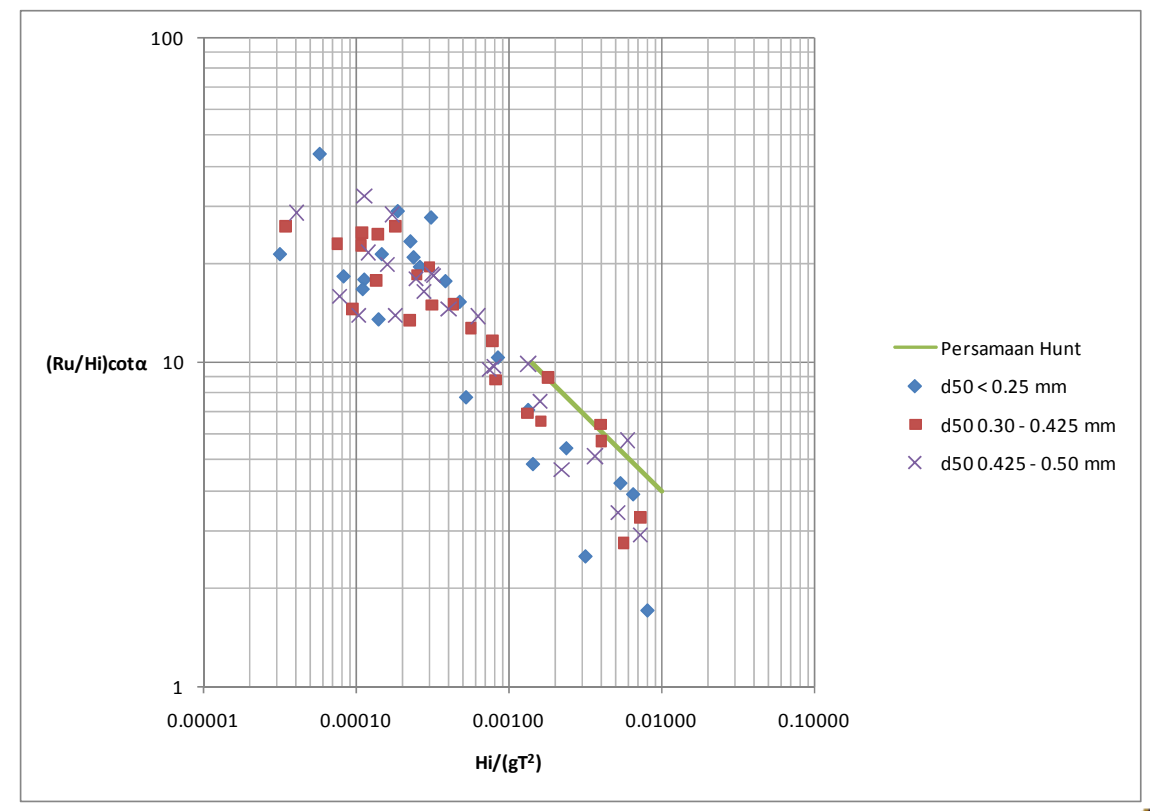

Gambar 9. Grafik Hubungan antara Profil Kemiringan $(\cot \propto)$ dan $\frac{H}{g T^{2}}$

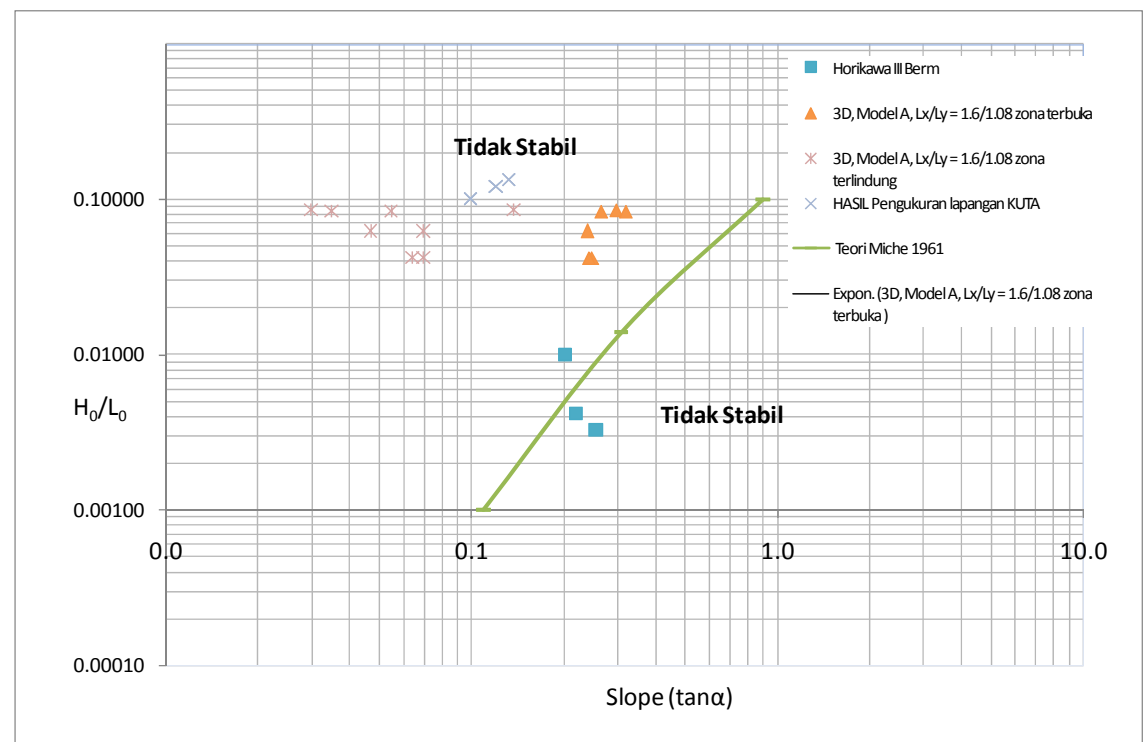

Gambar 10. Hubungan antara (slope) tan $\alpha$ dengan $H_{0} / L_{0}$, data hasil penelitian 3 D, Kajian Lapangan dibandingkan dengan dan teori Miche (1961).

\section{Kesimpulan}

1. Hasil verifikasi menunjukkan bahwa pada studi kasus lapangan kemiringan stabil dinamis yang dicapai adalah $\mathrm{nf}=5-10$, dengan kondisi tinggi gelombang $0.8-1.5 \mathrm{~m}$.

2. Parameter - parameter yang berpengaruh secara signifikan terhadap bentuk alignment garis pantai stabil adalah tinggi gelombang $(H)$, periode gelombang $(T)$ dan panjang gelombang $\left(L_{0}\right)$, sudut datang gelombang $(\theta)$, perbandingan antara geometri struktur $\left(L_{x}, L y, \mathrm{~B}\right)$ dengan panjang gelombang, yang dapat dirumuskan dalam hubungan matematis antar parameter. 
3. Hasil uji model fisik $3 \mathrm{D}$ untuk daerah terbuka, kemiringan stabil yang terjadi adalah berkisar $0.22 \leq \tan \alpha \leq 0.35$ dimana terjadi bar dengan kondisi $0.04<H_{0} / L_{0}<0.105$. Dari hasil analisa pengukuran di lapangan didapat bahwa kemiringan stabil yang terjadi adalah $0.1 \leq \tan \alpha \leq 0.2$ dengan $0.04<H_{0} / L_{0}<0.11$.

4. Diperlukan kajian teoritis lanjutan untuk mendukung analisa stabilitas profil kemiringan (nf) pada pantai pasir buatan sehingga profil kemiringan stabil terutama pada penelitian small scale maupun large scale dapat diketahui dengan baik.

\section{Ucapan Terima Kasih}

Ucapan terimakasih penulis sampaikan pada DP2M Dikti atas beaya penelitian dengan topik Stabilitas Pantai Pasir dan Interaksinya dengan Struktur Pelindung Pantai, melalui program Hibah Kompetensi. Penulis juga menyampaikan terima kasih kepada Pengelola Laboratorium Hidraulika Hidrologi, Pusat Studi Ilmu Teknik, UGM, serta Laboratorium Hidraulika - Hidrologi JTSL - UGM sehingga penelitian pada tulisan ini dapat terlaksana dengan baik.

\section{Daftar Pustaka}

Battjes J.A., Roos A. (no date). Characteristic of flow in Ru of Periodic Waves, Report no. 75-3, TU Delft, The Netherlands.

CEM. (2001). The Coastal Engineering Manual, Department of The Army, US Army Corps of Engineers, Washington DC.

CUR. (1987). Manual on Artificial Beach Nourishment, Centre for Civil Engineering Research, Codes and Specification Rijkswaterstaat, Delft Hydraulics.

Dean, R.G., and Dalrymple, R.A. (2002). Coastal Processes with Engineering Applications, Cambridge University.

Dong, P. (2008). Long - Term Equilibrium Beach Profile Based on Maximum Information Entropy Concept, Journal of Waterway, Port, Coastal, and Ocean Engineering (ASCE), Mey/June.

Horikawa, K. (1978). Coastal Engineering, an Introduction to Ocean Engineering, University of Tokyo.

Ping, W., Ebersole, B.A., and Smith, E.R. (2003). Beach-Profile Evolution under Spilling and Plunging Breakers, Journal of Waterway, Port, Coastal and Ocean Engineering, January, February.

Setyandito. (2009). Stabilitas Pantai Pasir Buatan, Proposal Usulan Penelitian untuk Disertasi, Program Pasca Sarjana S3 Teknik Sipil, FT. UGM Yogyakarta.

Swart, D.H. (1974). Offshore Sediment Transport and EBP, publication no. 131, TU Delft, The Netherlands.

Triatmodjo, B. (1996). Teknik Pantai, Betta Offset, Yogyakarta.

Yuwono, N. (2004). Pedoman Teknis Perencanaan Pantai Buatan (Artificial Beach Nourishment), Pusat Antar Universitas, Universitas Gadjah Mada Yogyakarta. 